\title{
Por Uma Dramaturgia Colaborativa
}

\author{
For A Collaborative Dramaturgy
}

por Phelippe Celestino

RESUMO

Este artigo debruça-se perante interrogações que perpassam a construção dramatúrgica desenvolvida ao longo do modo de criação conhecido como processo colaborativo. Tem por objetivo instalar e esclarecer questões acerca do tecido dramatúrgico oriundo deste método específico, por meio do levantamento e estudo de experiências de artistas e pesquisadores da cena contemporânea. 0 caminho escolhido inicia-se pela exposição da noção que compõe o termo dramaturgia na contemporaneidade, avança para explanação do processo colaborativo, encaminha-se para refletir a dramaturgia colaborativa e encerra-se numa elucidação da problematização da autoria e suas relações com o processo colaborativo. Percebe-se que é possível traçar características comuns entre os trabaIhos desenvolvidos e estabelecer prováveis parâmetros que evidenciam e identificam a dramaturgia que emerge desta prática específica de concepção cênica.

Palavras-chave: processo colaborativo, dramaturgia em processo, dramaturgia colaborativa, problemática da autoria, teatro contemporâneo

\section{ABSTRACT}

This article focuses towards questions that underlie the dramaturgical construction developed throughout the farming process known as collaborative. Aims to install and clarify issues about the dramaturgical tissue arising from this specific method, through the survey and study of the experiences of artists and researchers of the contemporary scene. The path chosen starts by exposing the notion of the term dramaturgy in contemporaneity, progresses for explaining the collaborative process, and addresses the collaborative dramaturgy related with the problem of authorship and the relations with the collaborative process. It was noticed that it is possible to trace common features between the works developed and establish probable parameters that identify and highlights the dramaturgy that emerges from this practice of scenic conception.

Keywords: collaborative process, work in process, collaborative dramaturgy, problem of authorship, contemporary scene, rhapsody writing 


\title{
Por Uma Dramaturgia Colaborativa
}

\section{Dramaturgias - Acepções e Delimitações}

\begin{abstract}
A palavra texto, antes de significar um texto falado ou escrito, impresso ou manuscrito, significava "tessitura". Nesse sentido, não há espetáculo sem "texto"'.
\end{abstract}

Antes de abordar as questões que envolvem a relação do modo de criação conhecido como processo colaborativo e a dramaturgia em processo, é preciso mencionar a amplitude acerca do termo dramaturgia recorrente na contemporaneidade. Segundo Eugênio Barba, todas possuem algo em comum: "o trabalho das ações no espetáculo" 2 .

A atual perspectiva diante do termo dramaturgia rompe com o paradigma clássico instaurado por Aristóteles, que indicou "dois campos de pesquisa diferentes: o texto escrito e a forma de representá-lo"3. Esta visão, que perdurou durante séculos, restringiu a dramaturgia apenas ao texto escrito, tornando-a o único foco de análise da manifestação teatral. Portanto, partir dessa premissa para pensar o teatro contemporâneo seria, no mínimo, negligente e anacrônico, visto que ao ampliarmos o termo dramaturgia ao trabalho de composição das ações - entendendo ação como todo tipo de interferência derivada dos elementos significantes que agem sobre o espectador - redimensionamos o espectro de seu estudo, pensando não somente o texto como proveniente do trabalho de composição das ações, mas também os outros elementos presentes na cena, como a luz, o cenário, o figurino e todos os componentes integrantes desse panorama.

Assim, dramaturgia, atualmente, expandiu sua aplicação, passando a ser atribuída ao trabalho de tessitura das ações que estão envolvidas nas diversas camadas que agem e modificam a estrutura teatral. Nessa acepção, ação "não é apenas o que é dito ou feito pelos diversos atores, mas também os sons, os ruídos, as luzes, as mudanças de espaço"4. Segundo Barba:

Ações são inclusive todas as relações, todas as interações entre os personagens entre si ou entre eles e as luzes, os sons, o espaço. Tudo o que age diretamente sobre a atenção do espectador, sobre sua compreensão, sua emotividade e sua cinestesia também é $a c ̧ a ̃ 0^{5}$.

Desse modo, texto está intrinsecamente relacionado à acepção de dramaturgia como tessitura de ações, "já o modo $0^{6}$ como as ações trabalham constitui a trama"7. Para Barba, a excelência de uma obra teatral reside na maestria do autor da encenação - portanto, o encenador - em equilibrar - e não harmonizar ou hegemonizar - dois tipos de tramas: 0 da concatenação e 0 da simultaneidade. 0 primeiro tipo diz respeito à relação

\begin{tabular}{ll}
\hline 1 & BARBA, 2012, p.66. \\
2 & Idem \\
3 & Idem \\
4 & Idem \\
5 & Idem \\
6 & Crifo meu. \\
7 & Idem
\end{tabular}




\section{Por Uma Dramaturgia Colaborativa}

sucessiva entre causas e efeitos, ou ainda, "de uma alternância de ações que represen-

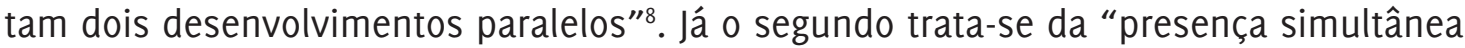
de várias ações" 9 - ressaltando que o conceito de ação está aqui empregado no sentido ampliado proposto por Barba.

Isso exposto, pretende-se neste artigo, abordar questões relativas à produção dramatúrgica realizada em processo colaborativo e, nesse sentido, priorizar as reflexões que se referem à dramaturgia enquanto escrita teatral, e não aquelas que envolvem a poética do espetáculo, ou seja, naquilo que vem sendo proposto como dramaturgia da luz, da cena, do ator, do espectador e de todos os outros elementos que compõem o evento cênico. Isso não significa dizer que o fato de não priorizar a análise da cena exclua a percepção da estreita "relação entre textualidade e materialidade cênica" (CAETANO, 2011, p.16), como também da influência que exerce sobre a escrita teatral, tornando-a, como veremos, um aspecto potencialmente material dentro da encenação, como afirma a pesquisadora Nina Caetano:

Como funções que guardam uma posição externa à cena e que são responsáveis por níveis estruturais em relação à criação da obra espetacular, encenação e dramaturgia acabam por ter, no âmbito da criação colaborativa, seu limites borrados, e talvez, não seja possível falar de uma dramaturgia espetacular sem confundir seu nível de atuação com o de uma poética da cena, própria do trabalho do encenador. (CAETANO, 2011, p.60)

\section{Processo Colaborativo - Perspectiva Histórica e Apontamentos Conceituais}

Entramos assim: como quem entra no escuro, nos lançando como crianças que brincam de cabra-cega. Medo e alegria inauguram o processo. 0 risco e a crença de que toda criação não deixa de ser um mergulho para dentro. ${ }^{10}$

0 processo colaborativo possui relação direta com a criação coletiva, visto que, em ambos, o corpo coletivo, entendido como o conjunto de pessoas envolvidas na criação, constrói a obra. Pode-se dizer que este modo de produção estruturado coletivamente perpassa duas fases na história do teatro brasileiro do século XX.

Nas décadas de 60 e 70, os grupos de teatro agregaram aos seus métodos de criação a ideologia política que os norteava socialmente, ou seja, devido à repressão e à opressão exercidas pelo regime militar, há uma busca pela ausência da hierarquia na organização dos coletivos teatrais, uma busca por uma criação livre da "ditadura" do texto ou autor-deus e na qual o ator possa ser, mais que mero intérprete, um compositor, de modo que todos fossem responsáveis pelo material produzido, não havendo um único autor da obra teatral, sendo a autoria um aspecto coletivo. Stela Fischer nos esclarece esta

\begin{tabular}{ll}
\hline 8 & Idem \\
9 & Idem \\
10 & RINALDI, 2002, p.45.
\end{tabular}




\title{
Por Uma Dramaturgia Colaborativa
}

ideologia quando descreve a criação coletiva:

\begin{abstract}
Característica comum aos grupos foi a revisão dos parâmetros de organização, horizontalizando o alinhamento das funções, resultando em uma descentralização das demandas do ato cênico muitas vezes restrita a estruturas de poder representadas pelo diretor e autor. Seguindo essa prerrogativa, o campo de interferência do ator ampliou-se, apropriando uma rede de atividades antes incumbidas a profissionais especializados" e "com a modificação das condições de criação, ele deixa de ser um especialista da arte de interpretar personagens. Por exigência de sua prática, aprende a adaptar ou criar textos coletivamente, imaginar, conceber e, às vezes, executar cenários e figurinos, organizar marcações, compor músicas" (...). (FISCHER, 2010, p.34)
\end{abstract}

Na década de 80 há um hiato: a prevalência do encenador como único autor da obra teatral. Este é quem detém em si todo o projeto artístico do espetáculo, sendo o seu pensamento e modo de trabalho as únicas matrizes para a construção da cena. Na década de 90 temos o nascedouro daquilo que hoje denominamos como processo colaborativo, que muito se assemelha à criação coletiva, sendo distinção primordial a presença de funções específicas e respectivos artistas responsáveis por esses papéis, que por sua vez, criam com a colaboração do coletivo. Nesse caso, a autoria é compartilhada, é "quase como se o processo colaborativo pudesse realizar uma síntese do discurso e da ideologia coletiva com a permanência da função artística individual" (ARAÚJ0, 2008, p.58).

Conceitualmente, entende-se por processo colaborativo o procedimento de grupo que integra a ação direta entre ator, diretor, dramaturgo e demais artistas, sob uma perspectiva democrática, ao considerar o coletivo como principal agente da criação e aglutinação de seus integrantes. Essa dinâmica propõe um esmaecimento das formas hierárquicas de organização teatral, embora com a imprescindível delimitação de áreas de trabalho e delegação dos profissionais que a representam (FISCHER, 2010, p.61).

É ainda esclarecedor quando Antônio Araújo, do grupo Teatro da Vertigem, se apropria de conceitos do teórico Roland Barthes, expostos em seu egrégio ensaio A Morte do Autor, e traça um paralelo com a estrutura que fundamenta o processo colaborativo, propondo que

Se pensarmos a "escritura coletiva" como aquela realizada por várias mãos, todas juntas escrevendo, ao mesmo tempo, um mesmo "texto", poderíamos associá-la a uma prática comum na criação coletiva. Ao contrário, a "escritura múltipla" definida como "um espaço de dimensões múltiplas", onde se casam e se contestam escrituras deve ser percorrido, e não penetrado", remete-nos ao território do processo colaborativo.

11 É este aspecto que nos interessa como distinção entre criação coletiva e processo colaborativo, na maneira como cada modo de criação se relaciona com as especificidades de cada função. Daremos curso a esta discussão mais adiante. 


\title{
Por Uma Dramaturgia Colaborativa
}

\begin{abstract}
Nele, os vários autores - ou autorias - não se somam, mas coabitam dentro da obra. As diferentes escrituras individuais estão ali mantidas, identificáveis, e o conjunto se forma não pela síntese entre elas, mas pelo diálogo e atrito, pelo choque de pólos artísticos particularizados, que se justapõem ou se contaminam, mas não se diluem um no outro. (ARAúj0, 2008, p.69)
\end{abstract}

Antônio Araújo busca, ainda, solucionar o equívoco diante da ideia de que o processo colaborativo e a criação coletiva sejam sinônimos e refiram-se à mesma prática. Seu argumento é que, pela perspectiva do método, poderíamos "pensá-los germinadamente" (ARAÚJ0, 2008: 59), mas que se observarmos a partir do modo, "perceberemos que o como se opera a inter-relação entre os diferentes elementos de criação produz, aqui, processos distintos" (idem). E acrescenta:

Outro aspecto importante diz respeito à síntese final. Se, na criação coletiva, a autoria individual - quando ela ocorre - deve estar submetida à vontade grupal, aqui ocorre um tensionamento ao limite entre estes dois pólos. Isto porque 0 artista responsável por uma área tem a palavra final sobre ela. (ARAÚJ0, 2008: 60)

É nesse horizonte de caráter processual, com relações recíprocas de colaboração que se desenvolve a dramaturgia colaborativa aqui em questão. E como veremos mais a fundo adiante, esse modo de criação pode atribuir ao texto emergido dele a mesma estética que o caracteriza, ou seja, uma dramaturgia onde todas as vozes criadoras são expostas e provocadas.

\section{Dramaturgia Colaborativa - Características e Reflexões}

\begin{abstract}
Um dramaturgo não-propositivo certamente não deixará marcas no texto e em sua estrutura, tornando-se apenas um "escriba", um organizador do material criativo produzido por outros ${ }^{12}$.
\end{abstract}

Definido o campo, gostaria de propor uma reflexão; Nina Caetano (2011, p.18) afirma que "a partir de Aristóteles, a teoria vai se debruçar sobre o estudo da dramaturgia como obra literária" e que essa perspectiva vai perdurar até a segunda metade do século XX, quando é rompida pelas experimentações do alemão Bertolt Brecht, nas quais alguns teóricos acreditam ter surgido a processualidade dramatúrgica. 0 encenador e dramaturgo que gerou o Teatro Épico produzia suas peças e as levava para a sala de ensaio e ao público, afim de observar sua funcionalidade e potência, sendo os resultados matrizes para possíveis alterações na dramaturgia.

Outro fator que podemos evidenciar no trabalho desenvolvido por Brecht é a presença de todos os elementos materiais da cena na composição do texto, podendo, assim, agregar à sua dramaturgia um caráter de materialidade capaz de emergir para a superfície características que compõem a estética da cena.

12 CAETANO, 2011, p.140. 


\section{Por Uma Dramaturgia Colaborativa}

Noutras palavras, no teatro brechtiano é inaugurado, certamente, o conceito de dramaturgia da cena, uma vez que a atividade dramatúrgica já não diz respeito somente à composição do texto escrito. No Teatro Épico, proposto por Brecht, a processualidade dramatúrgica está intrinsecamente relacionada à criação do espetáculo - teatralidade e textualidade como faces da mesma moeda - e de toda a equipe de montagem se torna responsável pela criação da obra cênica como um todo ${ }^{13}$.

Essa incursão no pensamento dramatúrgico culminou em uma crítica em torno da qualidade literária das dramaturgias emergidas de métodos coletivos de criação, nos quais o dramaturgo deixa de ser aquela figura exilada em seu gabinete e alheia ao processo de construção da cena. 0 encenador Antônio Araújo nos esclarece a questão e aponta perspectivas.

Devemos ficar atentos a tal aspecto, na medida em que existe muito preconceito em relação a textos escritos no bojo de uma dinâmica grupal. Por exemplo, a dramaturgia produzida pela criação coletiva é, até hoje, vista com enormes ressalvas - 0 que mereceria uma revisão mais criteriosa. É claro que muitas das peças produzidas eram fracas estruturalmente e pecavam por panfletarismo e superficialidade no tratamento dos temas. Contudo, isto é diferente de rotular toda aquela produção simplesmente como "má dramaturgia". E esse mesmo fantasma parece também rondar os textos criados em processo colaborativo. ${ }^{14}$

Portanto, excluir a potencialidade cênica do texto teatral como critério de análise é, no mínimo, injusto, visto que este se realiza efetivamente na cena - não deveria ser esta a preocupação primordial do dramaturgo? Diante disso, é excepcionalmente potente, do ponto de vista cênico, o texto elaborado de modo processual, no qual todas as suas funcionalidades são testadas e reinventadas, compartilhando da instabilidade processual imanente a criação teatral.

A pesquisadora Nina Caetano, em sua tese de doutoramento, descreve as características da dramaturgia colaborativa e as suas relações com conceitos ligados à Teoria do Caos ${ }^{15}$, reforçando a potencialidade criativa e cênica deste modo de produção dramatúrgica.

Assim, a dependência sensível às condições se refere a permeabilidade do dramaturgo em relação a quaisquer elementos surgidos em conversas ou improvisações que possam suscitar nele "todo um manancial de novas ideias e possibilidades de desenvolvimento do texto". 0 conceito de imprevisibilidade diz respeito à percepção do dramaturgo em relação às alterações - propositais ou acidentais - que possam ocorrer durante os ensaios ou apresentações e implica no aproveitamento dessas mesmas alterações - que podem ser ruídos ou flutuações - para o enriquecimento da obra em construção. E, por fim, o conceito de complexidade está relacionado a uma percepção mais ampla de que a obra é resultante das interações ocorridas entre os participantes do processo de criação, e que, em função disso, ela está sempre "em permanente evolução, continuamente se reprocessando e se auto-organizando". (CAETANO, 2011: 80)

13 CAETANO, 2011, p.34

14 ARAÚJ0, 2008, p.66.

15 REWALD, Rubens. Caos/Dramaturgia. São Paulo: Perspectiva; Fapesp, 2005. 


\title{
Por Uma Dramaturgia Colaborativa
}

Acredita-se que, para avançarmos nossa reflexão, é imprescindível nos desvencilharmos da concepção clássica e perceber que o texto teatral, antes de ser literário, tem de ser material, ferramenta para a cena, compondo a obra, e não a regendo, contaminando e sendo contaminado constantemente pela criação de todos os artistas envolvidos no processo teatral. É evidente que o processo colaborativo não é o único modo de criação para o teatro e, consequentemente, para o texto teatral, contudo é inegável sua potência no que se refere às relações entre texto e cena, devido a seu caráter processual e transitório que permite ao dramaturgo propor e experimentar seu material, interpelando e adequando-o aos seus próprios desejos e do coletivo.

\begin{abstract}
A dramaturgia, destituída da ideia de texto fixador ou imutável, não é mais vista como o objeto de onde emana a encenação, mas como um elemento em constante transformação, e o dramaturgo, com um "estatuto de precariedade e provisoriedade igual ao dos outros criadores da cena", acaba por se tornar tão dependente dos ensaios para o desenvolvimento de sua obra quanto o ator e diretor. ${ }^{16}$
\end{abstract}

Assim, pode-se pensar a dramaturgia colaborativa como resultante de uma tessitura própria do processo colaborativo de criação, de modo que a heterogeneidade e multiplicidade intrínsecas a este modo de criação, rompem com a homogeneidade e unidade presentes na teoria do drama absoluto e, assim, a dramaturgia transforma-se em forma aberta e ramificada. Graças à coexistência e interação de diversas vozes na criação (CAETAN0, 2011, p.62), o texto teatral adquire uma identidade polifônica, como definida por Bakhtin em sua análise da obra de Dostoievski ${ }^{17}$, ou seja, resulta na existência simultânea de elementos heterogêneos que não anseiam a unidade e a harmonia, mas a confluência e a justaposição de elementos heterogêneos.

\begin{abstract}
A dramaturgia - e a cena - produzida em processo colaborativo vai incorporar essa presença de planos distintos, identificáveis, por exemplo, no amplo espectro de registro, no cruzamento de referências, no choque de discursos, na estrutura fragmentada e no mosaico de textos e cenas. 0 elemento dramático coabita com 0 épico, o lírico, o testemunho, o documental criando uma cena - e um texto - multifacetada. (ARAÚJ0, 2008, p.80)
\end{abstract}

Apesar dessa estética ser, antes de tudo, uma tendência, e não uma norma para toda dramaturgia originada de um processo colaborativo, a identidade polifônica vai se referir "à garantia, na superfície do texto mesmo, do cruzamento de vozes presentes na sala de ensaio" (CAETAN0, 2011, p.149), cabendo ao dramaturgo dar ao seu material um tratamento capaz de manter o caráter polifônico presente no processo do qual emergiu o texto, ou seja, cabe a ele a "investigação de procedimentos que possam tornar possível à dramaturgia, como fruto de uma experiência de colaboração, fazer-se polifônica" (CAETAN0, 2011, p.149).

16 CAETANO, 2011, p.58.

17 BAKHTIN, Mikhail. Problemas da poética de Dostoiévski. Rio de Janeiro: Forense Universitária, 1987. 


\title{
Por Uma Dramaturgia Colaborativa
}

\begin{abstract}
Em uma dramaturgia polifônica (...) a heterogeneidade dos diversos elementos significantes presentes no tecido dramatúrgico da cena, é resultante de um modo de produção não somente coletivo, mas que deseja o confronto entre as vozes criadoras, garantindo sua miscibilidade e equipolência. (...) sem dúvida alguma, o texto colaborativo deverá refletir, na apropriação linguística que faz da matéria cênica, 0 processo polifônico que o engendrou. (CAETANO, 2011, p.63)
\end{abstract}

A pesquisadora Sílvia Fernandes também ressalta a relação existente entre textualidade e materialidade cênica no texto originado do processo colaborativo que deu origem ao espetáculo Apocalipse 1,11 do Teatro da Vertigem.

No texto, Fernando Bonassi projetava soluções também cênicas - espaciais, gestuais, cinéticas - como se compartilhasse com o diretor o papel de escritor de ações, imagens e movimentos. É interessante notar que essas projeções invadiam as falas das personagens, compondo uma cena imaginária quase independente, como se 0 dramaturgo usasse a prática coletiva, os improvisos do elenco e as descobertas da pesquisa de campo para a composição de um roteiro de falas, espaços e gestos. ${ }^{18}$

Antônio Araújo, apontando as características estéticas da obra resultante de um processo colaborativo, diz que na dramaturgia poderia ser

Apontada ainda a existência de um elemento fragmentário, de justaposição de cenas sem forte ligação causal, produzindo uma estrutura dramática mais aberta e ramificada. Tal configuração, marcada por elementos de colagem, intertextualidade e cadeias de leitmotiv, é resultado direto do conjunto diversificado de vozes artísticas presentes no processo, e poderia incorrer em flacidez estrutural em peças “colcha-de-retalho". (ARAÚj0, 2008, p.67)

De agora em diante, me atento à exposição da escrita rapsódica, proposta pelo teórico francês Jean-Pierre Sarrazac em o futuro do drama, evidenciando sua potência em transpor à dramaturgia colaborativa a heterogeneidade e multiplanaridade presente no processo colaborativo.

"Estabeleçamos hoje as bases de uma estética contra naturam. E penetremos, sem medo, no antro do monstro" (SARRAZAC, 2002, p.28). Natureza, nesse sentido, abriga uma acepção clássica de perfeição e beleza, de conformidade a fins ${ }^{19}$, porém sem representação de um fim $^{20}$ semelhante estabelecida pelo filósofo do século XVIII Immanuel Kant, que na sua discussão sobre o juízo de gosto tenta estabelecer quais são os mecanismos que despertam prazer no ser humano e o faz definir um objeto como Belo. Para ele, a "Beleza é a forma da conformidade a fins de um objeto, na medida em que ela é percebida nele sem representação de um fim" ${ }^{21}$. Deste modo, entendo que a proposta de Sarrazac, parte em oposição a este modelo, e em direção a monstruosidade, a desarmonia, ao hibridismo, ao interesse, a heterogeneidade, a multiplicidade e 0 18 FERNANDES, 2002, p.39.

19 KANT, 1997, p. 108.

20 Idem

21 Idem 


\title{
Por Uma Dramaturgia Colaborativa
}

desequilíbrio.

\begin{abstract}
Texto monstruoso, texto híbrido, patchwork ideal das peças escritas (e mesmo das não escritas) ao longo dos últimos anos, texto diferencial e utópico concebido não como um modelo, mas sim como uma quimera, como uma criatura efêmera destinada a fazer-nos sonhar, a partir das promessas do presente, com o futuro múltiplo da obra dramática. (SARRAZAC, 2002, p.24)
\end{abstract}

Visto isso, qual seria a forma que abriga estas possibilidades? Ao compor drama no título de sua tese, Sarrazac não tem como objetivo remeter ao gênero estritamente dramático, como estabelecido por Aristóteles, "é bem pelo contrário, emancipando-se da noção de gênero" 22 seu desejo é se dedicar ao drama desenvolvido durante a segunda metade do século XX, oriundo da Crise do Drama, como descrita na Teoria do Drama Moderno de Peter Szondi. Segundo o teórico húngaro, a crise é caracterizada pela dificuldade encontrada pela forma tradicional em expressar o conteúdo coetâneo, visto que "a "dramaturgia épica" surge à medida que se precipita em forma a relação sujeito-objeto do conteúdo" (SZONDI, 2011, p.83), e deste modo, percebe-se que "não basta dizer coisas novas, é preciso, também, dizê-las de outra forma"23, e para Sarrazac, "nem transcendente aos gêneros, nem gênero em si mesmo, o drama moderno representa, a meu ver, uma das formas mais livres e mais concretas da escrita moderna"24. Szondi nos mostra essa irrupção do conteúdo a forma quando observa que "a objetividade com que os "lavradores do carvão" da Silésia apareciam para o pesquisador social de fora na obra de Hauptmann é transportada por Brecht do plano contingente da temática, para 0 institucional da forma"25.

Além desta incongruência forma clássica e conteúdo contemporâneo, por que amalgamar dramático e épico? Para Sarrazac, esta fusão realiza uma ampliação do campo de atuação do texto teatral, visto que a forma dramática pertence/remete ao presente, a proximidade, ao que está no aqui e agora do tempo absoluto do drama, composto por "individualidades fixadas no seu papel subjetivo"26; e a épica constitui-se daquilo que The é externo, "a dimensão do distante" ${ }^{27}$. Portanto, segundo Sarrazac, podemos concebê-las desse modo: a "peça dramática é lisa, sem ondulações, o seu desenho/ilustração de eleição é o matizado, a obra épica é franzida, com riscas e todos os sentidos, o seu efeito dominante é o contraste"28. Assim, pensar em uma superação da forma dramática em beneficio a plenitude da forma épica é restringir o campo de abrangência do texto teatral, visto que é possível, segundo Sarrazac, uma fusão dessas duas esferas: o épico e o dramático. Não é nossa finalidade uma radicalidade formal que almeja a homogeneidade e harmonia, pois como foi citado, o intento é penetrar "sem medo, no antro do monstro" 29 .

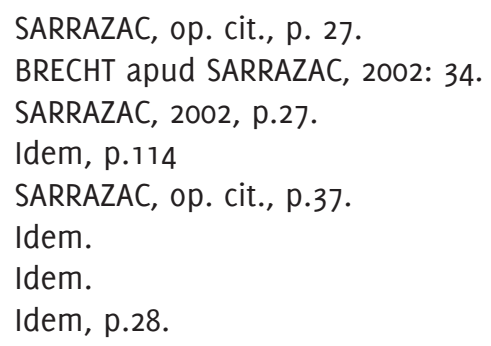




\section{Por Uma Dramaturgia Colaborativa}

Pois então, por que a escrita rapsódica tenderia a transpor à superfície do texto teatral a multiplicidade e heterogeneidade das relações contidas no modo de criação dado como colaborativo? 0 ponto de partida possível para esta resolução é pensar nesta associação de alteridades, enquanto circunstância que se constrói por relações de diferença e de contraste. A simultaneidade de duas formas heterogêneas, dramática e épica, justapostas num mesmo plano, se equipara à relação e disposição das diversas vozes presentes no processo colaborativo. Desse modo, o trabalho dramatúrgico no modo processo colaborativo tende a ser do escritor-rapsodo proposto por Sarrazac, como sendo aquele "que junta o que previamente despedaçou e, no mesmo instante, despedaça o que acabou de unir"30, tecendo assim, na superfície do texto, as diversas e distintas materialidades envolvidas no processo de construção da obra teatral.

Pode-se pensar, isso posto, as características e diretrizes comuns às dramaturgias resultantes do modo de criação colaborativa, sem, no entanto, deixar-se cair na armadilha do dogmatismo e da normatividade, pois "cada assunto tem uma teatralidade que the é própria e é a procura das estruturas que exprimem essa teatralidade que forma uma peça" ${ }^{31}$, e não obstante, que "a forma é um reservatório do conteúdo e as formas antigas deixam transpirar as velhas ideologias" 32 .

\section{Problemática da Autoria - Instauração e Esclarecimentos}

A escrita é esse neutro, esse composto, esse obliquo pelo qual foge o nosso sujeito, o branco-e-preto em que vem se perder toda identidade, a começar pela do corpo que escreve. ${ }^{33}$

É pertinente discutir a autoria no processo colaborativo, pelo fato de haver constantes e mútuas interferências e contaminações entre as diversas instâncias de criação, sendo muitas vezes questionado quem seria o verdadeiro autor de tal texto, uma vez que ele foi criado pelo ator mas manipulado e utilizado pelo dramaturgo, ou uma decisão estética derivada do texto que se efetiva na encenação, e até mesmo uma proposição de cenário do iluminador que integra a cena.

Também é importante ressaltar que a autoria foi o que fundamentou toda a história do teatro tradicional, desde a antiga, e em parte, a moderna. A importância e presença de um determinado autor em um período específico da história sempre foi a matriz principal para se pensar o teatro de uma época em sua totalidade. Tomemos como exemplo, Shakespeare e o Teatro Renascentista.

Portanto, pretende-se neste momento do artigo, entender se é possível pensar esta função $0^{34}$ numa criação derivada de um processo fundamentado por um corpo coletivo,

\footnotetext{
$30 \quad$ Idem, p.37.

31 GATTI apud SARRAZAC, 2002, p.34.

32 HEGEL apud SARRAZAC, 2002, p.33.

33 BARTHES, 2004, p.57.
}

34 Essa distinção nos é imprescindível: função e sujeito são termos que correspondem a modos distintos no pensamento de Foucault em torno da problemática da autoria. 0 primeiro diz mais respeito 


\section{Por Uma Dramaturgia Colaborativa}

no qual todas as vozes são expressas e de crucial relevância.

Em uma notável conferência para a Sociedade Francesa de Filosofia em 1969, intitulada 0 que é um Autor? ${ }^{35}$, Michel Foucault discute a problemática da autoria numa perspectiva direcionada à propriedade, mais especificamente ao poder e à responsabilidade, que foi sendo atribuída historicamente e socialmente ao sujeito autor.

Enfim, o nome autor funciona para caracterizar um certo modo ele ser do discurso: para um discurso, o fato de haver um nome do autor, o fato de que se possa dizer "isso foi escrito por tal pessoa", ou "tal pessoa é o autor disso", indica que esse discurso não é uma palavra cotidiana, indiferente, uma palavra que se afasta, que flutua e passa, uma palavra imediatamente consumível, mas que se trata de uma palavra que deve ser recebida de uma certa maneira e que deve, em uma dada cultura, receber um certo status.(FOUCAULT, 2006, p.273)

Se pensarmos a tessitura de um espetáculo como sendo um processo de transcrição cênica dos diversos elementos presentes no processo e que integram a cena, é possível entender que não há possibilidade de atribuir a autoria do espetáculo a um único autor, visto que na obra estão presentes a contaminação e interferências, diretas ou indiretas, de todos os artistas criadores envolvidos no processo de criação teatral. Assim, pensar o dramaturgo ou encenador como autor da obra é, tendo em vista a história da sociedade, colocar um sujeito como único detentor da obra, tanto de seu âmbito intelectual, quanto artístico, e isto, seria injusto e incoerente com a posição ideológica que estrutura o processo colaborativo.

Essa noção do autor constitui o momento crucial da individualização na história das ideias, dos conhecimentos, das literaturas, e também na história da filosofia e das ciências. Mesmo hoje, quando se faz a história de um conceito, de um gênero literário ou de um tipo de filosofia, acredito que não deixa de considerar tais unidades como escansões relativamente fracas, secundárias e sobrepostas em relação à primeira unidade, sólida e fundamental, que é a do autor e da obra. ${ }^{36}$

“Mas o essencial não é constatar mais uma vez seu desaparecimento; é preciso descobrir, como lugar vazio - ao mesmo tempo indiferente e obrigatório -, os locais onde sua função é exercida" (FOUCAULT, 2006, p.264). A partir disto, é excepcionalmente coerente a suposição de que a autoria no processo colaborativo trata-se de uma função intrinsecamente relacionada com a manipulação e estruturação de um discurso do que com o próprio ato demiurgo de criação, visto que neste último reside o pensamento de algo que é original e etéreo, e no primeiro habita a revelação de um material a partir de uma experiência singular e coletiva: o processo. Isto relaciona-se mais diretamente ao campo da descoberta, do que ao da criação.

à funcionalidade/tarefa, e o segundo a propriedade.

35 FOUCAULT, Michel. Literatura e Pintura, Música e Cinema. Rio de Janeiro: Forense Universitária, 2006, p. 264.

36 Idem, p.267. 


\title{
Por Uma Dramaturgia Colaborativa
}

É possível pensar, a partir dessa prática, em três figuras, levantadas por Rubens Rewald 37 , em seu estudo: "o autor-scriptor produz o texto que é, em seguida, apreciado e criticado pelo autor-leitor e autor-espectador vai constituir seu processo de escritura a partir das mediações feitas em cena por atores e encenador" (CAETANO, 2011, p.91).

Assim, nos é revelado que o autor não é uma unidade que se restringe unicamente a sua própria subjetividade, mas sim uma função na qual um ser é capaz de materializar as múltiplas instâncias que existem na sua subjetividade em constante relação com os círculos que o envolve, sendo eles de ordem afetiva, social, econômica, histórica e coisas que tais. A vista disso, o dramaturgo ou encenador não é capaz de conservar em si todos os sentidos do espetáculo, cabendo ao leitor perceber os sentidos que lhe foram despertados, sendo que estes, muitas vezes, podem se divergir daqueles despertados no artista que executa a função de autor. É necessário que se entenda que o autor não é capaz de decidir com certeza o que o leitor vai apreender da obra, há uma margem para idealização, que por sua vez não pode ser confundida com fixação, tentando tornar imutável e definida uma dimensão que é volátil e imensurável.

\begin{abstract}
Eu os resumirei assim: a função-autor está ligada ao sistema jurídico e institucional que contém, determina, articula o universo dos discursos; ela nasce, se exerce uniformemente e da mesma maneira sobre todos os discursos, em todas as épocas e em todas as formas de civilização; ela não é definida pela atribuição espontânea de um discurso ao seu produtor, mas por uma série de operações específicas e complexas; ela não remete pura e simplesmente a um indivíduo real, ela pode dar lugar simultaneamente a vários egos, a várias posições-sujeito que classes diferentes de indivíduos podem vir a ocupar. (FOUCAULT, 2006, p.279)
\end{abstract}

Portanto, se passarmos à prática da sala de ensaio no processo colaborativo, o dramaturgo no exercício de sua função observa as experiências ocorridas no processo, e a partir disto des-cobre algo que ali emana, e este material, por sua vez, está potencialmente contaminado pelas relações dos artistas com o processo e do próprio dramaturgo com a sociedade. Nesse sentido, não há criação e nem propriedade, mas sim descoberta, captura e aglutinação, que ocorre através da percepção singular de uma subjetividade, mas que está em constante fricção com o coletivo. Desse modo, esta subjetividade atribui uma estética particular ao material emergido deste processo, tornando o artista um descobridor, existe em primeiríssima instância a sua identidade no material resultante, contudo, esta não será capaz de anular a interferência e contágio que houveram dos outros artistas. E poderíamos traçar um paralelo também com a descoberta do ator, que constrói seu material a partir das relações com os outros artistas envolvidos no processo, e análogo é o processo do encenador, do cenógrafo, do figurinista e do iluminador. Portanto, há a função autor, mas esta não abriga uma totalidade de significação da obra, pois esta somente se completa na relação entre a escritura e o destinatário, ou seja, 0 leitor no ato da fruição.

Foucault nos chama atenção para o fato de que se trata de inverter o problema tradicional, e não mais colocar a questão: como a liberdade de um sujeito pode se inserir na consistência das coisas e lhe dar sentido? Como ela pode animar, do interior, as regras 


\title{
Por Uma Dramaturgia Colaborativa
}

de uma linguagem e manifestar assim as pretensões que lhe são próprias? Mas antes colocar: como, segundo que condições e sob que formas, alguma coisa como um sujeito pode aparecer na ordem dos discursos? Que lugar ele pode ocupar em cada tipo de discurso, que funções exercer, e obedecendo a que regras? Trata-se, em suma, de retirar do sujeito (ou do seu substituto) seu papel de fundamento originário, e de analisá-lo como uma função variável e complexa do discurso.

Outro importante filósofo francês que estuda a autoria é Roland Barthes, que coloca $A$ Morte do Autor ${ }^{38}$ como sendo necessária para o nascimento do leitor, e a partir desta metáfora, nos fica claro o sentido que esta figura, cultivada pela história crítica e literária, não é capaz de deter em si, em seu sujeito, toda a origem e voz da sua escritura. Isto acontece pelo fato de que o ato de escrever é um ato de transposição de todo um manancial de palavras que o escritor possui em si, mas que não se restringe apenas nele, ultrapassando sua própria individualidade e encontrando plenitude no leitor. Cada leitor é uma entidade que possui a função capaz de assimilar uma dimensão singular da multiplicidade de significações e citações oriundas das várias culturas presentes na escritura, criando assim, seu próprio texto. Dessa forma, um texto não é um texto, mas vários textos, que nascem no ato da fruição.

É pertinente ressaltar que este leitor aqui examinado não se trata do indivíduo, mas da entidade, isenta de identidade, espaço e tempo; capaz de executar a ação que the é própria: a leitura; que por sua vez diz respeito ao verdadeiro lugar de emergência da origem e vozes da escritura. Ao escritor é reservado o ato performático, de manipular, no instante da escrita, as palavras que compõem sua interioridade, impregnada de interações culturais e sociais, agregando as palavras inúmeros sentidos, múltiplos e diversos, que não se limitam somente a sua história e vida. Isso é o que torna a escrita plural, revela a relevância do destinatário, e faz alcançar o seu propósito vital: a leitura.

\begin{abstract}
Assim se desvenda o ser total da escritura: um texto é feito de escrituras múltiplas, oriundas de várias culturas e que entram umas com as outras em diálogo, em paródia, em contestação; mas há um lugar onde essa multiplicidade se reúne, e esse lugar não é o autor, como se disse até o presente, é o leitor: o leitor é o espaço mesmo onde se inscrevem, sem nenhuma se perca, todas as citações de que é feita uma escritura; a unidade do texto não está em sua origem, mas no seu destino, mas esse destino já não pode ser pessoal: o leitor é um homem sem história, sem biografia, sem psicologia; ele é apenas esse alguém que mantém reunidos em um mesmo campo todos os traços de que é constituído o escrito. ${ }^{39}$
\end{abstract}

Sabido que todos os elementos da cena atuam na criação do dramaturgo no processo colaborativo, e que todas as suas dimensões tradicionais foram rompidas e ampliadas, entendemos o porque ele é incapaz de deter em si toda a autoria de uma obra teatral. Assim, mesmo que o dramaturgo seja o responsável por manipular textualmente todas as vozes presentes na criação, o exercício de sua função não instaura hierarquização, mas "uma contínua flutuação entre subordinação e coordenação, fruto de um dinamismo associado às funções e ao momento em que o trabalho se encontra" (ARAÚ)0, 2008,

38 BARTHES, Roland. 0 Rumor da Língua. São Paulo: Martins Fontes, 2004, p.

39 BARTHES, op. cit., p.64. 


\title{
Por Uma Dramaturgia Colaborativa
}

p.61).

Desse modo, cada artista atua conforme sua função e especificidade, de modo que o trabalho particular atinge e é atingido por todas as esferas que compõe o espetáculo, agregando a dramaturgia, uma personalidade múltipla e heterogênea, onde todas as vozes criadoras são expressas. Dito isso, pensar o conjunto da obra teatral fundada no corpo coletivo como sendo de autoria de um único indivíduo, é negligenciar aquilo que está manifesto e latente no próprio modo de criação.

\begin{abstract}
Ao descolar a unidade do texto do autor para o leitor, Barthes vai permitir que se conceba tanto a dramaturgia - como prática textual e cênica - quanto o texto resultante desta operação, como um espaço em que se reúnem dimensões múltiplas, originadas no embate entre as diversas escritas, ou melhor, entre os diversos gestos de inscrição que, livres de determinação de um autor-deus, vão compor o tecido dramatúrgico: o gesto do dramaturgo, mas também o gesto do ator, do encenador e de todas as funções vinculadas à sua criação. (CAETANO, 2011, p.40)
\end{abstract}

Doravante, à luz de Barthes e Foucault, pode-se pensar na autoria de obras resultantes de processos colaborativos como sendo uma função compartilhada e em duas instâncias. A primeira com os indivíduos no processo de criação, e a segunda, mais radical e profunda, com toda a cultura que compõe 0 artista envolvido no processo colaborativo. Assim, não podemos mensurar uma autoria, pois ela transcende qualquer indivíduo que integre um corpo coletivo. Subvertemos o gesto da criação, e agregamos ao seu conceito a noção de des-cobrir: um sensivel, infinito e constante gesto de des-velar, transparecendo à superfície o que há, de poético e sublime, submerso. 


\section{Por Uma Dramaturgia Colaborativa}

\section{Referências Bibliográficas}

> ARISTÓTELES. A poética. Tradução Eudoro de Souza. São Paulo: Ars Poética, 1992.

> ARAÚJ0, Antônio. A encenação no coletivo: desterritorializações da função do diretor no processo colaborativo (tese de doutorado). São Paulo: Universidade de São Paulo, 2008.

> BARBA, Eugênio; SARAVESE, Nicola. Dicionário de Antropologia Teatral. São Paulo: É Realizações, 2012.

> BARTHES, Roland. A morte do autor in 0 Rumor da Língua. São Paulo: Martins Fontes, 2004.

> CAETANO, Nina. Tecido de vozes: texturas polifônicas na cena contemporânea mineira (tese de doutorado). São Paulo: Universidade de São Paulo, 2011.

> FERnANDES, Sílvia; ARAújo, Antônio; CARVALHO, Sérgio de; et al. Trilogia Bíblica. São Paulo: Publifolha, 2002.

> FISCHER, Stela. Processo colaborativo e experiências de companhias teatrais brasileiras. São Paulo: Hucitec, 2010.

> FOUCALT, Michel. 0 que é um Autor? In Estética: Literatura e Pintura, Música e Cinema. Rio de Janeiro: Forense Universitária, 2006.

> KANT, Immanuel; DUARTE, Rodrigo (Org.); et al. Parágrafos selecionados da crítica da faculdade do juízo in 0 Belo Autônomo, textos clássicos de estética. Belo Horizonte: Editora UFMG, 1997.

> SARRAZAC, Jean-Pierre. 0 Futuro do Drama. Porto: Campo das Letras, 2002.

> SZONDI, Peter. Teoria do Drama Moderno (1880-1950). São Paulo: Cosac Naify, 2011.

Phelippe Celestino, estudante-pesquisador do grupo de pesquisa HIBRIDA-Poéticas Híbridas da Cena Contemporânea (CNPQ). Atua em pesquisas que possuam ênfase em Dramaturgia e Direção Teatral. É um dos fundadores, e atual coordenador, do Coletivo seráFIM, criado na UFOP em 2011, por graduandos do curso de Artes Cênicas. Além disto, durante 2013 desenvolveu o projeto TEXTURAS: Laboratório de Textualidades Cênicas Contemporâneas, financiado pelo PIP/UFOP (Programa de Iniciação à Pesquisa da UFOP), e que deu origem ao artigo aqui presente. Atualmente desenvolve o projeto ESCRITÚDIO - Ateliê de escrita teatral, financiado pelo PROBIC/FAPEMIG/UFOP (Programa de Bolsas de Iniciação Científica e Tecnológica da FAPEMIG). Ambos os projetos sob a orientação da Prof. Dr. Elvina Caetano. phelippe.celestino@gmail.com 